\title{
"False Friends" and Some Other Phenomena Reflecting the Historical Determination of the Terminology of Hungarian Private Law
}

\section{András Földi ${ }^{1}$}

Published online: 28 May 2020

(c) The Author(s) 2020

\begin{abstract}
This article deals with some phenomena of the Hungarian legal language from a historical point of view, with special regard to the terminology of private law going back to Roman law tradition. The author aims, on the one hand, to present the historical background of the current terminology of Hungarian private law by means of some representative examples. On the other hand, it is attempted at demonstrating that "false friends" and some further misunderstandings in the current terminology of Hungarian private law can be led back to the historical determination of the concepts/terms in question. A certain Hungarian legal language existed already in the 16th c., however it reached the common European level by the middle of the 19th c. This development took place mainly under the influence of the Austrian and German law and legal science. Due to the translation of foreign legal terms to Hungarian since the 19th c. there emerged some "global" difficulties of legal terminology also in the Hungarian legal language. As the most important example, the reception of bona fides can be mentioned. It was an amendment of the Hungarian Civil Code in 2006 which tried to eliminate the misunderstandings as regards the principle of good faith (and fair dealing) conceived formerly by many Hungarian jurists exclusively in subjective sense. The history of reception of the German notions of Gültigkeit and Wirksamkeit in Hungary is extremely intriguing, too. Hungarian jurists did not follow the pattern of the German BGB but developed this pair created by Windscheid by drawing a clear distinction between the validity and effectiveness of legal transactions (as well as of the legal norms), similar to the Italian terminology (validità v. efficacia). Sometimes the reception of German notions happened in a less successful way (e.g. in the case of negatives Interesse created by Jhering, which can be qualified as a "false friend" in Hungary in comparison with the original German notion). Despite the important foreign, especially German impacts, the
\end{abstract}

The author expresses his gratitude to his esteemed colleague, Máté Paksy for the friendly invitation to the special issue and for the valuable help given in order to improve the present article.

Extended author information available on the last page of the article 
Hungarian legal language is an autonomous one having several remarkable features which deserve attention also in comparison with terminology of the Western legal cultures.

Keywords Roman law $\cdot$ Reception $\cdot$ Autochthonous language $\cdot$ Neologism $\cdot$ Law of contracts $\cdot$ Good faith $\cdot$ Nullity $\cdot$ Interest

\section{Introduction}

The present article deals with some phenomena of the Hungarian legal language from a historical point of view, with special regard to the terminology of private law going back to Roman law tradition. My aim is, on the one hand, to present the historical background of the current terminology of Hungarian private law by means of some representative examples. On the other hand, it is attempted at demonstrating that "false friends" and some further misunderstandings in the current terminology of Hungarian private law can be led back to the historical determination of the concepts/terms in question.

These purposes shall be reached through application of historical and comparative methods covering mainly the comparative history of private law and to some extent also the historical and comparative linguistics with the reservation that not being a linguist but a jurist, the author has only a limited competence as regards the linguistics. ${ }^{1}$

As far as the notion of "false friends" is concerned, it is well-known that these words are from different languages which seem prima facie to be the same, but which have different meanings. ${ }^{2}$ An Italian legal comparatist and EU lawyer, Benacchio, quoting abundantly further literature as well, refers to a number of false friends. Albeit not using this technical term, Benacchio refers to the difference, e.g., between the "obligation" in terms of English law and the obligation of French law as well as the homologous obbligazione of Italian law [19: 37]. Also the difference between the cause of (former) French law and the causa of Italian law is dealt with by the Italian author [19: 38].

Identification of such terms leads to misunderstandings. As for the origin, essence and disadvantageous consequences of such misunderstandings, the present article will offer examples reviewing both the Hungarian development and its European context.

\footnotetext{
${ }^{1}$ As regards the literature of linguistics, a Hungarian monograph [31], a Hungarian article [28], two old (i.e. 19th c.) Hungarian dictionaries [38, 39], furthermore various general, etymological as well as legal dictionaries of Latin, German, French and Hungarian languages [1, 2, 4, 9, 21, 25, 32, 41] were consulted.

2 The notion of "false friends" (faux amis) has been introduced in the literature of linguistics by Maxime Koessler and Jules Derocquigny in 1928 [29].
} 


\section{On Historical Development of Hungarian Legal Language in General}

The Hungarian legal language reached the common European level by the middle of the 19th century. Previously, being the official language of Hungary until 1844, the Latin language prevailed. ${ }^{3}$ The antecedents of Hungarian legal language are not to be underestimated. A Hungarian translation of Werbőczy's Tripartitum by Balázs Weres (published in 1565) proves that a certain Hungarian legal language existed already in the 16th c. and obviously had to exist earlier as well. It is, however, discussed, how far the antecedents of Hungarian legal language can be traced back. ${ }^{4}$

Although the vocabulary of Hungarian legal language contained from the beginning autochthonous Hungarian terms, foreign (especially Latin, Slavic, German, and recently English) words have continuously been received or literally translated to Hungarian.

The influence of Austrian and German law and legal science became exceptionally significant from the beginning of 19th c. and this fact determined the intensive reception of German legal terms. Between 1849 and 1860 the official language of Hungary was the German language and this fact strengthened obviously the influence of German legal language. The impact of the German legal language concerned both the development of the Hungarian legal terminology and the way and style of legal explanations in Hungarian [58: 433].

\section{On the Autochthonous Hungarian Legal Terms}

First, I shall deal with the autochthonous Hungarian legal terms. If I qualify certain Hungarian legal terms as "autochthonous", I do not mean that such words could be led back to the remote past. I mean much rather that they were created independently (more or less) from foreign denominations of the given legal notion.

Already the Romans had the problem, how to name the guarantor (in French caution, in German Bürge). The substantive adpromissor could have been a suitable term for accessory debtors but it was only occasionally used, ${ }^{5}$ while as result of a

\footnotetext{
3 As for the change from Latin to Hungarian it is characteristic that Ignác Frank (1788-1850), professor of private law in the University of Pest (today Budapest) published his treatise on the Hungarian private law first in Latin (Principia juris civilis Hungarici, I-II, Pestini 1828-1829), however, 16 years later the revised and enlarged edition of this work was published already in Hungarian [18]. Frank had an important role in the creation of Hungarian legal terminology [22: 375; [46]: 221].

4 Kovács [31: 179] claimed that Hungarian legal language was born simultaneously with the foundation of the Kingdom of Hungary in 1000 A. D. and from the beginning the bilingualism of Latin and Hungarian existed. Of course, it seems worth presuming that the most important legal terms had always a Hungarian equivalent (unless they were simply "Hungarized" like the term testamentom ['will'], for which see infra) but even if their existence could be documented for the Middle Ages, it is doubtful whether the Hungarian legal terms existing in the early times constituted the critical mass for qualifying their sum as Hungarian legal language.

5 It is characteristic that in the title 45.1 (De obligationibus et actionibus) of the Digest the word adpromissor can be found in one passage only (Pomp. 26 ad Sab., D. 45.1.5.2), while the word fideiussor occurs not less than 31 times in the same title. A still larger disproportion (2:330) can be verified in
} 
long development the word fideiussor became the mostly used term for the guarantor in the imperial age. The substantive fideiussor meant originally and literally a debtor who assumed an obligation by means of a stipulation containing the words fide iubeo. The content of such a stipulation was not necessarily the assumption of suretyship. However, a positive correlation came into being between the use of fideiussio and the assumption of suretyship, and in this way the fideiussio became the most important denomination of suretyship. It is to be supposed that a semantic narrowing down took place in the course of development of the term fideiussor. ${ }^{6}$

This terminology has determined the Italian denomination of guarantor as fideiussore (see Art. 1936 of the Italian Codice civile of 1942).

The French development followed the same model for some centuries. In the French language the word fidéjusseur was the conventional term of guarantor until the 14th c. Then, however, the word caution spread in the meaning 'guarantor' and pushed soon the more complicated word fidéjusseur into the background [32]. The French denomination caution can be regarded as a bit surprising since it was originally an abstract notion going back to ancient Roman law [41]. It is remarkable that the current French meaning of the word caution has hardly anything to do with its etymological origin. Considering these circumstances, we can regard the French term caution as a peculiar surrogate applied as the guarantor's denomination faute de mieux. The current French term caution can be at the same time a dangerous false friend for Hungarian jurists if they suppose that caution meant in French some kind of caution money paid in advance by a debtor as a pecuniary guarantee for his future duties.

As far as the denomination of the guarantor is concerned, a more advantageous development took place in the German language, which has an autochthonous and adequate term for the guarantor, namely the substantive Bürge. This word documented already in the Middle Ages goes back to the verb bürgen and referred originally to the fact that the guarantor was invited to the conclusion of a contract of loan [9]. ${ }^{7}$

The Hungarian term for the guarantor, too, namely the word kezes seems to be an autochthonous term. It is related with the Finno-Ugrian substantive kéz (in Finnish käsi) which means 'hand'. This word documented in legal meaning since the 15 th c. referred to the custom that the guarantor confirmed the assumption of obligation by means of handshaking. The problem referred to above as regards the fideiussor

\footnotetext{
Footnote 5 (continued)

the title D. 46.3 (De solutionibus et liberationibus). The word adpromissor occurring quite seldom in the sources seems to be so much modern that some Romanists attributed it to postclassical or Justinianic interpolation, however e.g. Kaser [27: 661] rejected this suspicion.

6 As a notorious example of the semantic narrowing down the development of meaning of the Latin word manus in Roman law can be mentioned. The word manus in its abstract sense (i.e. when it did not mean 'hand') meant originally the pater familias's power in general including his power upon his wife, his children as well as his slaves. Later, however, the abstract meaning of manus tended to narrow down to the marital power.

7 Unfortunately, I could not rely on Der Bürge einst und jetzt: Festschrift für Alfons Bürge, hrsg. Ulrike Babusiaux, Peter Nobel und Johannes Platschek, Zürich: Schulthess, 2017.
} 
emerges also in this case since handshaking was used not only at assumption of suretyship. As for the traditional rite of engagement, a woman who was proposed marriage would offer her hand in acceptance [49: 327ff]. A semantic narrowing down, if it was necessary, took place in the case of the word kezes very quickly, as it can be supposed on the basis of etymological dictionaries [2, 4].

The Hungarian language has an autochthonous term also for the contractual penalty (in Latin poena conventionalis, in German Konventionalstrafe). The corresponding Hungarian substantive kötbér being used also nowadays (see the new Hungarian Civil Code [Act No. V of 2013], Section 6:186-189) was created in the second half of the 19th c. ${ }^{8}$ Unaware of this word, Ignác Frank used a provisory (or perhaps an improvised) term instead, namely szószegés díja ['fee of perfidy'] [18: 595]. In a Hungarian legal dictionary published in 1843 (hereinafter TTM) the entry poena conventionalis is still missing [38]. The word vinculum, which should be according to Frank a synonym for the contractual penalty, was translated in the TTM [40] as 'penitentiary money' (bánatpénz, being a literal translation of the German Reugeld). The meaning 'penitentiary money' is given also at the entry vincularis poena by the TTM [40]. These facts show that it was not easy to find the final term, and in addition there was a standing risk of confusion of contractual penalty with similar legal institutions. ${ }^{9}$

Despite the difficulties at the outset, the term kötbér emerged and became quickly dominant in the second half of the 19th c. It is not quite clear why just this term was finally preferred. The word kötbér has namely a semantic deficiency insofar it means literally a "payment on the basis of an obligation". That is why it could have in the beginning perhaps a wider meaning. However, as it seems, the neologism kötbér did not need a semantic narrowing down, it meant probably already in statu nascendi the contractual penalty only. ${ }^{10}$

The (perhaps) autochthonous Hungarian term for earnest (in Latin arrha poenalis, in German Draufgabe [in Germany], Angeld [in Austria], Haftgeld [in Switzerland]) is the word foglalo (see the Sect. 6:185 of Act No. V of 2013). Originally it was named foglaló pénz i.e. a sum of money (pénz) by which a thing to be sold was reserved for the buyer. ${ }^{11}$ In the course of its development the substantive pénz. ['money'] was omitted and the participle foglaló became an independent substantive in the specific legal meaning 'earnest'.

\footnotetext{
${ }^{8}$ While Bozóky [5: 359] used instead of kötbér still the word bírság ['fine, penalty'], Suhayda [45: 249] used already the current terminology for earnest (foglaló), pentientiary money (bánatpénz) as well as for contractual penalty (kötbér).

${ }^{9}$ Confusion of penalty and penitentiary money, which is present in the TTM [38], is understandable if considering that in these cases, in contrast to the earnest, a certain sum of money is not paid immediately to the other party but only in a later stage when some lesion of the duty took place. If such a sum of private law penalty is being paid simultaneously with conclusion of the contract, it is to be qualified as earnest. When payment in advance does not have a penal function, it can be qualified as advance money or deposit (caution) [16: 71ff].

${ }^{10}$ As referred to above, Suhayda [45: 249] distinguished the kötbér unambiguously from the similar legal institutions.

${ }^{11}$ The verb foglal is in use also in contemporary Hungarian language, e.g. in the meaning to reserve a table in a restaurant.
} 
The Hungarian equivalent of "price", the word ár-having otherwise some surprising homonyms - is of Finno-Ugrian origin. Its original meaning is not known. Later it meant 'value'. The current meaning is first documented in the 12th c. [4].

\section{Reception of Foreign Legal Terms in Hungarian Language}

As for the earliest foreign impacts on the development of Hungarian language, the (first) impact of the Turkish language has to be stressed which took place already in the centuries before Hungarians arrived in the Carpathian Basin. This early impact is attested in the legal language e.g. by the words kölcsön ['loan'] and bér ['rent, fee'; in Latin merces] [4]. The Turkish origin of these words show the higher economic level of Turkish population in those centuries.

Some Hungarian legal terms were borrowed from Slavic languages in the Middle Ages, like the substantives ispán ['bailiff'], ${ }^{12}$ pénz ['money'], ${ }^{13}$ kár ['damage'], ${ }^{14}$ zálog ['pledge'], ${ }^{15}$ kamat ['interest'; in German Zins]. ${ }^{16}$ These words being signs of development of public administration and of commerce, attest that Slavic people (especially Serbs and Croatians) reached a certain level of these spheres earlier than Hungarians. It is a well-known fact that Serbian merchants had an outstanding role in Hungary for many centuries.

As far as the impact of the Latin language is concerned, it is to be noted that Roman law was never received in Hungary, it had, however, some impact on the development of Hungarian law already in the Middle Ages [22: 131ff, 372ff]. On the other hand, as referred to above, Latin was the official language of Hungary until 1844. This fact is understandable if we consider that the Kingdom of Hungary was always a multi-ethnic country, and the Latin language served as lingua franca for learned people of all the nationalities. The longe durée of Latin as official language of Hungary can be explained also with the concern of Hungarian gentry that in the case of abolition of Latin the German language would have prevailed. ${ }^{17}$

There are many examples for direct reception of Latin terms with slight Magyarization. Such a phenomenon is quite natural in the Neo-Latin languages, but in the Hungarian language it has not been regarded as normal since the beginning of the 19th c. When Benjámin Nánásy published his book on the testamentary successions in 1798 [34], there was not yet an autochthonous Hungarian term for the will, therefore it was named testamentom on the basis of the Latin term testamentum. In the TTM there are not less than twelve synonyms formed in the first half of the 19th

\footnotetext{
12 First documented in the 13th c. It is probably of Slavic origin (zhupan) [4].

13 13th c. It was borrowed from a Slavic language and meant originally coin. A more remote root is the German Pfennig [4].

14 14th c. It was borrowed from a Slavic language [4].

15 15th c. It was borrowed probably from the Croatian zalog [4].

16 The Serbo-Croatian kamata goes back to the Greek kamatos. [2, 4].

17 This scenario was eventually realized, first in the time of the Emperor Joseph II (between 1784 and 1790), and a second time after the failure of the liberty war in 1849, when German became again the official language of Hungary until 1860.
} 
c. for the Hungarian denomination of testamentum [38]. In the first place the word végrendelet [literally 'final disposition'] was mentioned, which was preferred also by Frank [18: 431ff], and which is in use nowadays as well (see the Sects. 7:12ff of Act No. V of 2013).

Some terms of Latin origin are living elements of the present-day Hungarian legal language. As a notorious example the Hungarian substantive uzsora can be mentioned which goes back to the Latin usura. This word appeared in Hungarian perhaps in the time of foundation of the Kingdom of Hungary and it can be documented since the 14th c. [28: 59ff]. The word meant in the beginning probably interest in neutral sense, however its pejorative connotation connected with the creditors' abusive conduct became soon dominant. This word (or its derivates) can be found both in the new Hungarian Civil Code of 2013 (the sedes materiae of the uzsorás szerzódés ['usurious contract'] is the Section 6:97 of Act No. V of 2013) and in the new Hungarian Criminal Code of 2012 (see the Section 381 of the Act No. C of 2012 treating the uzsora-büncselekmény ['crime of usury']).

It is more frequently the case that Latin terms have been translated to Hungarian. Such a translation took place as regards the Latin term obligatio, on the basis of which the Hungarian equivalent kötelem was created not later than in 1831 [2]. This new word was one of the great many products of the reformation of Hungarian language which began as a cultural movement at the end of the 18th c. and reached its apogee in the first half of the 19th c. Although also the German word Verbindlichkeit (used already e.g. by Kant and Lessing [21]) could be the source, the Hungarian verb kötelez ['to oblige'] going back to the ancient Finno-Ugrian verb köt ['to bind'] was used in legal meaning as early as in the 14th c. [4]. Maybe it is on the basis of chronological considerations that this usage of the verb kötelez is led back by the etymological dictionaries to Latin origin [4].

It was not a quick development that the neologism kötelem spread as denomination of obligation. In the TTM not less than twelve Hungarian equivalents of the obligatio can be found, however, the kötelem was not included there [38]. Frank [18: 545] preferred the word tartozás. ${ }^{18}$ This Hungarian word corresponds to the Latin debitum and to the German Schuld (in contradistinction to Haftung). Searching for the Hungarian equivalent of obligatio János Henfner ascertained in 1856 that it is impossible to express the various meanings of obligatio with a single Hungarian term. Henfner thought that all the Hungarian legal expressions derived from the verb köt ['to bind'] and in this way also the substantive kötelem had been connected with the debtor's duty, while the obligatio meant the whole legal relationship between the creditor and the debtor including therefore also the creditor's rights [23: III, 1f].

Regarding these circumstances it is remarkable that the substantive kötelem could assume the meaning obligatio. I think that this development could take place since kötelem was a more abstract word than the similar words kötelezettség ['duty'] and kötelezés ['imposing a duty'] connected more closely to the debtor's duties. The term kötelem spread in the second half of the 19th c. and is a fundamental notion of

\footnotetext{
18 The word tartozás was registered in the TTM [38], s. v. as the fourth Hungarian equivalent of obligatio.
} 
Hungarian civil law nowadays as well (see the Book 6 of Act No. V of 2013 entitled Kötelmi jog ['Law of obligations']).

A further example of translation of Latin legal terms is óvadék ['caution money'] which is a more or less literal translation of the Latin term cautio ['the taking of precautions, care, circumspection', 'a precautionary measure']. ${ }^{19}$

As far as the impact of German legal language is concerned, some German words were directly received in a Hungarized form. The Hungarian word for citizen (polgár) goes back to the German Bürger. This reception took place as early as in the 14th c. [4]. In this way the mayor is named in Hungarian also nowadays polgármester which is an exact equivalent of the German term Bürgermeister. The German legal terms received in this way (e.g. móring ['dowry', cf. Morgengabe]; soltész ['a kind of mayor', cf. Schultheiß) became mostly obsolete [4].

A considerable part of the current Hungarian legal vocabulary is constituted by words which have been literally translated from German. Notorious examples of this kind are the Hungarian terms for acquisitive and extinctive prescription. Their creation is interesting especially in comparative historical context.

The acquisitive prescription is named in contemporary Hungarian elbirtoklás (see the Sections 5:44-5:49 of Act No. V of 2013). This word is in relation with the verb birtokol ['to possess'] and with the deverbative birtoklás ['possessing']. It was created not later than in 1835 ([39: II, 247], s. v. Ersitzung), ${ }^{20}$ however, it cannot be found among the seven Hungarian equivalents of usucapio registered in the TTM [38] and Frank [18] did not use it either. ${ }^{21}$

Henfner named the acquisitive prescription átruházó elévülés ['übertragende Verjährung'] and alternatively also elbirtoklás ['Ersitzung'] [23: II, 68]. Why did Henfner regard the term elévülés_-documented first in 1837 [4] —as a hypernym covering not only the extinctive but also the acquisitive prescription? In order to understand Henfner's terminology_inspired by the Austrian civil code being effective in the time of publication of his textbook-it is necessary to refer briefly to the antecedents going back to Roman law. ${ }^{22}$

For many centuries the Romans knew only the acquisitive prescription which was coined usucapio during the classical period. Some early forms of the extinctive prescription emerged only in the early imperial age when the praescriptio longi temporis appeared. This expression referred to a special exception of the "long time". It was given to the defendant possessing a provincial real estate (fundus provincialis)

\footnotetext{
19 See [20], cf. [41]. The history of the Latin term cautio and its huge impact on the development of European languages would deserve an independent study. In Hungarian legal language there exists a slightly Hungarized equivalent of the Latin cautio, namely the word kaució. As it has been referred to above, the French caution and the Hungarian kaució can be especially dangerous "false friends".

20 This passage is quoted as the earliest record (still in the obsolete form elbirtokolás) in [1], s. v.

21 Frank [18: 239] tried to find a Hungarian equivalent for acquisitive prescription as well as for usucaption but his alternative terms seem to be of improvised character. The terminological difficulties were connected with the fact that in old Hungarian private law the acquisitive prescription i.e. the usucaption was not (or not generally) recognized [57: 243f].

22 It is to be remarked that the textbooks used by Henfner as a model, applied different terms for acquisitive prescription (usucaption), namely Schilling [40: 447ff] used the term "erwerbende Verjährung", while Haimberger [53: 60ff] used the term "Ersitzung".
} 
for 10 or 20 years against the action (rei vindicatio utilis) instituted by the quasiowner of the same real estate.

Later some terminological as well as conceptual confusion emerged since new forms of extinctive prescription appeared which tended to assume also acquisitive character when the defendant was possessor of a real estate. As a result of the former trends the meaning of usucapio was narrowed down in the Justinianic law to the usucaption of movable things, while for the usucaption of real estates the not quite new term praescriptio longi temporis was introduced.

The classical praescriptio longi temporis as a special kind of exceptio concerning a specific type of extinctive prescription constituted the origin both of the general rule of extinctive prescription (praescriptio XXX vel XL annorum) laid down in a constitution of Theodosius II (in 424) as well as of the acquisitive prescription of real estates (praescriptio longi temporis) enacted by Justinian. Justinian introduced in addition also an extraordinary acquisitive prescription (praescriptio $X X X$ vel $X L$ annorum) [6: 141ff; slightly differently [35]: 193].

It is superfluous to observe, what an enormous impact these legal institutions had on the later history of European private law. In the medieval French law the usucaption of movable things disappeared and in this way the prescription could become a hypernym covering all the types of acquisitive and extinctive prescriptions.

In German legal culture, however, this terminology did not apply. On the contrary, the autochthonous German terms Verjährung (first documented in the 16th c.) and Ersitzung (first documented in the 17 th c.) rendered possible a sharp distinction between the extinctive and acquisitive prescription [21].

The German terminology of prescription is advantageous not only because of its distinctive character but also because of its linguistic adequacy. The Latin term praescriptio, regarding its etymology, does not have anything to do either with the essence of the acquisitive or with that of the extinctive prescription. ${ }^{23}$ The German terms refer, however, to an essential moment of the legal institutions in question, namely to the possession and to elapsing of the years respectively. Notwithstanding elapsing of years is essential also as regards the acquisitive prescription, therefore the German terminology is not entirely logical in this respect.

The Hungarian terminology of both types of prescription was determined by the corresponding German terms, which have literally been translated to Hungarian and spread in the course of the 19th c. Forging definitive Hungarian terms of these legal institutions was, however, neither an easy nor a quick process. The various

\footnotetext{
23 The praescriptio means literally only words which are written in the beginning of a (legal) text, namely in the beginning of the text of a lex adopted by the comitia or in the beginning of the text of a formula emitted by the praetor. Its meaning 'exception' came into being in connection with the fact that some important exceptions of the defendant were included in the praescriptio of the praetorian formula. My students in the first year, if not yet aware of these historical antecedents, ask me sometimes wondering, why the Roman word praescriptio means 'acquisitive/extinctive prescription' instead of 'legal provision', while the more familiar German word Vorschrift means in fact '[a kind of] provision', in accordance with its Hungarian equivalent elöírás being literally translated from German. My students are often surprised when I tell them that also the French word prescription means first of all 'acquisitive or extinctive prescription' rather than 'legal provision'. In this way both the Latin praescriptio and the French prescription can be false friends for Hungarians having only a limited knowledge of legal terminology.
} 
Hungarian equivalents given by the TTM [38] seem to be of improvised character. ${ }^{24}$ It was only in the second half of the 19th c. that the terms eléviulés and elbirtoklás became dominant.

It is a recent development that some English terms like "factoring" and "leasing" have appeared with slight Magyarization of orthographic character in the text of the new Civil Code of Hungary (Act No. V of 2013, Sections 6:405ff, 6:409ff). Moreover, in a remarkable way, the notion of "franchising" has been received in the text of the new Civil Code without Magyarization of its orthography (see the word franchise in the Sections 6: 376ff).

\section{Some Global Problems of Legal Terminology and Their Presence in the Hungarian Legal Language}

Due to the translation of foreign legal terms to Hungarian since the 19th c. there emerged some "global" difficulties of legal terminology also in the Hungarian legal language. As the most important example, the reception of bona fides can be mentioned.

The notion of bona fides going back to Roman law (translated to English with the not quite innocent term "good faith" [19: 37f; [26]: 1253]), apart from its further meanings, has par excellence an objective and a subjective meaning. These two different meanings are expressed in German since the entering in force of the BGB (1900) by the technical terms Treu und Glauben and guter Glaube respectively.

If the terminology of a given legal culture does not have but one technical term for both meanings of the good faith only, the risk of confusion of the two meanings remains present [48: 12]. Formerly in the most civil law jurisdictions, similarly otherwise to common law jurisdictions [7: 198ff], a kind of "subjective monism" prevailed, namely the good faith was regarded as a subjective state of mind also in the law of contracts. In Austria, however, a kind of "objective monism" has traditionally prevailed, i.e. the good faith referred to as Redlichkeit has been an objective standard also in the law of things [36: 229ff]. The global development of the notion of good faith can be described grosso modo as a development from the dominance of subjective monism to that of the dualism in terms of terminological distinction of the two basic meanings of good faith. The Hungarian development follows to this global trend $[14,17]$.

The Hungarian equivalent of the term good faith (and fair dealing) was created slowly. The Bill of a Private Law Code for Hungary in 1928 fixed in its Sect. 2 the term jóhiszemúség és tisztesség ['good faith and honesty'] as denomination of the objective good faith. The subjective good faith was referred to simply as jóhiszemúség ['good faith'] in the Sect. 3. This solution was inspired by the Swiss

\footnotetext{
${ }^{24}$ In the TTM [38] there were four Hungarian synonymous equivalents for Verjaehrung, and, as mentioned above, seven synonyms for usucapio, not to speak about the thirteen synonyms for praescriptio. One of the most ancient Hungarian translations of praescriptio was idómúlás ('elapsing of time'), see the Tripartitum, I, 78 as translated by Balázs Weres (Debreczen, 1565).
} 
Civil Code. ${ }^{25}$ The terminology of the Bill of 1928 could not safeguard an unambiguous distinction of the two notions in Hungary in the subsequent decades.

From 1949 the concept of "good faith and honesty" was regarded in Hungary as being incompatible with socialist civil law. ${ }^{26}$ Therefore, instead of this formula, the para. 1 of Sect. 4 of the Hungarian Civil Code of 1959 (Act No. IV of 1959) laid down that "[i]n the course of exercising their rights and fulfilling their duties the parties in civil law relations shall display such a conduct that enforcement of their interests shall be in harmony with the interest of society." The para 2. laid down that "[i]n civil law relations [the parties] shall cooperate mutually and act in compliance with the requirements of socialist coexistence. Cooperation shall be realized by the exact fulfilment of the duties and by such an enforcement of rights which is in compliance with their [social] destination."

As regards the Preliminary provisions of the Civil Code of 1959, the expression "good faith" did not disappear totally in their text, since the Sect. 6 laid down that "[t]he court may obligate to full or partial reparation the person whose intentional behaviour has induced another person in good faith to such a conduct whereby the latter has suffered a damage through no fault of his own." However, this reference is connected basically with the subjective good faith of the possible plaintiff, while it is only in indirect relationship with the objective good faith.

After entering in force of the Civil Code of People's Republic of Hungary on 1st of May 1960 for some decades "good faith" survived in Hungarian civil law as an exclusively subjective notion. This development was useful in a way because between 1960 and 1991 it allowed that Hungarian lawyers not to confuse the two meanings of good faith, at least surely not within the Hungarian civil law. Notwithstanding the elimination of principle of good faith and honesty caused considerable misunderstandings when a Novel in 1991 (Act No. XIV of 1991), overwriting the corresponding socialist formula, re-introduced the classical principle of "good faith and honesty". Even a number of highly qualified Hungarian jurists supposed then, and also some years later that the good faith mentioned in this passage would be identical with the subjective good faith known especially in the law of things [12: 59ff].

\footnotetext{
${ }^{25}$ See the para 1. of Sect. 2 (with reference to Treu und Glauben) and the Art. 3 of the Swiss Civil Code (with reference to guter Glaube). While the German text of the Swiss Civil Code applies, similarly to the German BGB, an absolutely clear distinctive terminology in these passages, the distinction of the two meanings of bonne foi (buona fede) is less evident in the French and Italian versions of this code.

${ }^{26}$ The same condemnation applied also as regards the principle of prohibition of contracts "contrary to good morals (and public order)" which was also laid down in Sect. 973 of the Bill of 1928, following the example of (old) Art. 1133 of the French Code civil. That is why in para. 2 of Section 200 of the Civil Code of 1959 a socialist formula was substituted for the classical principle concerning the contracts contra bonos mores. The socialist formula contained a reference to an "evident" conflict with "the interests of the working people or to the requirements of socialist coexistence". It was only the Novel of 1991 which restored the classical formula, preserving the adverb "evidently" (which was otherwise inspired probably by the para. 2 of Art. 2 of the Swiss Civil Code), and at the same time, omitting the reference to the public order mentioned in the Bill of 1928. As it is known, in 2016 a significant reform of the French Code civil cancelled the references to bonnes moeurs in some passages preserving only the reference to the ordre public.
} 
This fact is a remarkable sign of the global problem that the term "good faith" used in the context of objective good faith and fair dealing can be an extremely dangerous "false friend" when jurists not aware of the semantic dualism of the good faith suppose that good faith has to mean always the good faith in subjective sense.

In December 2005, the Hungarian parliament amended (through the Act No. III of 2006) the text of the Civil Code of 1959 (having been in force with several amendments until 2014) in order to eliminate the confusion of the subjective and objective meanings of the good faith [14: 53ff; [17]: 312ff.] In the new Hungarian Civil Code (Act No. V of 2013) the terminological corrections of the Novel of 2006 apply (see the para 1. of Section 1:3 as well as the para 1. of Section 6:102 of the Act No. V of 2013, with references to jóhiszemüség és tisztesség ['good faith and honesty']).

A similar terminological problem concerning the buona fede has emerged in Italy on the occasion of implementation of the EEC directive 93/13. From the beginning a number of Italian jurists have criticized the ambiguous expression "malgrado la buona fede" in the Art. 1469-bis inserted into the Codice civile in 1996 (which still survives in the Art. 33 of Codice del consumo of 2005) [19: 37].

The history of reception of the German notions of Gültigkeit and Wirksamkeit (contradistinguished for the first time by Windscheid) in Hungary is extremely intriguing, too. Since 1900, the German jurists influenced by the terminology of the BGB have preferred to use the word Wirksamkeit in the meaning 'invalidity', although this notion was named by the Pandectists (e.g., by Savigny) themselves Gültigkeit, while the term Wirksamkeit tended to mean 'effectiveness' (of the legal transactions) in the late Pandectistics. ${ }^{27}$

The Hungarian legal terminology did not follow the terminology of the BGB but developed the late Pandectistic terms by drawing a clear distinction between the notions of validity and effectiveness of legal transactions (as well as of legal norms). Creation of the corresponding Hungarian terms took place in 1914. It was the merit of Gáspár Menyhárth, a professor of private law in the University of Kolozsvár (today Cluj-Napoca in Romania) to have introduced the terms érvénytelenség ['invalidity'] and hatályosság ['ineffectiveness'] in Hungarian legal language [33: 269ff]. ${ }^{28}$ This terminology was received in the Civil Code of 1959 (see in particular the para. 1 and 2 of Section 237 as well as the Sections 644-653 of Act No. IV of

\footnotetext{
27 It was Windscheid who first tried to distinguish the Ungültigkeit conceived as invalidity from Unwirksamkeit conceived as ineffectiveness [56: I, 423, 444ff, 461, 471]. A clear and well-founded distinction between the Ungültigkeit and Unwirksamkeit was made first by Figge [10]. See more thoroughly [11: 73ff; [42]: 342ff].

${ }^{28}$ It is interesting that in the same year (1914) a professor of the University of Lemberg, namely Ernst Till published a study with a similar message, namely suggesting the clear distinction of Gültigkeit and Wirksamkeit [50: 209ff]. Albeit there were some antecedents of such a distinctive terminology, see especially Imre Zlinszky [57: 116ff], the contradistinction of érvényesség and hatályosság was not yet wellfounded in Zlinszky's work. He did not explain, on the one hand, the corresponding doctrine and, on the other hand, even the title of his work is not coherent with the terminological distinction applied eventually by him, since Zlinszky should not have referred to the érvény ['validity'] but much more to the hatály ['effectiveness'] of Hungarian private law treated by him. These developments escaped even the attention of Iván Siklósi in his comprehensive monograph [42].
} 
1959) and it applies also in the new Civil Code of 2013 (see, in particular, the Sections 6:118 and 7:37-7:47 of Act No. V of 2013).

It is needless to deny that the concept of ineffectiveness is not well-founded. Due to this immanent deficiency and also due to some inaccurateness committed during the codification (namely due to the uncritical reception of expressions used in former drafts having a less distinguished terminology ${ }^{29}$ ) both the former and the new Hungarian civil codes lay down that a testament (i.e. a will) loses its effectiveness if the testator withdraws the will. Effectiveness of the testaments before the testator's death seems to constitute a contradiction if considering the meaning of effectiveness in the Hungarian law of contracts [11, 42, 43].

Despite this slight deficiency, the Hungarian terminology of invalidity and ineffectiveness is to be regarded in my modest opinion as a great achievement in the global history of the legal notions. As far as I know, such a clear contradistinction of these notions is not known in the Western legal cultures except the Italian civil law. ${ }^{30}$ Nevertheless, an analogous clear distinction of these notions is known e.g. in Russian civil law, too, in which the substantives dejstvitelnost and dejstvie are used in terms of validity and effectiveness respectively (see the Art. 166-181 of Grazhdanskij Kodeks Rossijskoj Federacii of 1994).

It is an interesting phenomenon as regards the history of the influence of Pandectistics that some late Pandectistic ideas have been followed in some Eastern European legal systems and also in Italy. It would be interesting to verify whether such efforts have taken place also in further East European legal systems.

As a recent important achievement of the Hungarian legal language the clear and well-founded distinction of four spheres of the civil law liability lato sensu can be highlighted. These four spheres, which can be led back in a way to Roman law, ${ }^{31}$ are as follows: the normal civil law (contractual and extracontractual) liability (felelösség), the liability of guarantors, heirs, etc. (helytállás), the warranty (szavatosság), and the bearing the risks (veszélyviselés). ${ }^{32}$ During the preparation of the new Civil Code of 2013 it was a priority that the expressions related with normal civil law (i.e. contractual and extracontractual) liability (felel, felelös, felelösség) shall not occur in those passages of the Civil Code in which one of the other three types of (strict) liability are treated.

\footnotetext{
29 The former drafts of a Hungarian civil code-including the Bill of 1928 (sections 1957-1962)qualified the withdrawal of testaments as a case of rendering a testament ineffective (hatálytalanítás). However, in the terminology of the former drafts the terms érvényesség and hatályosság were not contradistinguished in terms of validity and effectiveness, much more they were treated as synonyms. As an important sign of the undistinguished use of the two terms can be referred to the fact that the other case of "hatálytalanítás" was the impugnment of testaments (see the Sections 1953-1956 of the Bill of 1928) which would be named today "érvénytelenítés" [11, 42, 43].

30 In Italian legal language it is customary to distinguish between the validità and efficacia of legal transactions, see e.g. [37: 363ff; [44]: 19ff], see, however, also [51: 192].

$31 \mathrm{Cf}$. e.g. the division of titles concerning the emptio venditio in the Digest on the basis of distinction of normal contractual liability (D. 19.1), warranty (D. 18.5) and bearing of risks (D. 18.6).

32 As for the contradistinction of the liability in narrower sense on the one hand and the debts on the other, see [25: 1084, cf. [13]: 89ff].
} 
Occasionally the reception of German legal notions took place in a less successful way in Hungary. As for the positives and negatives Interesse created by Jhering in 1861 [24], a problematical metamorphosis of these notions has emerged in Hungary. The "positive interesse" has meant in Hungary for many decades the full indemnification including also the compensation of lucrum cessans, while the "negative interesse" has meant the reimbursement of the costs emerging due to concluding a void contract. ${ }^{33}$

We may take as granted that not every Hungarian lawyer has realized perfectly that the attributes "positive" and "negative" were not connected with the higher or lower amount of indemnification. As it is known, the introduction of these terms by Jhering into the legal language was purported to make manifest the difference that in case of positive interesse the indemnification had to be paid as if the valid contract of the parties had been correctly fulfilled, while in case of the negative interesse the damages had to be paid as if the parties had not concluded their invalid contract at all. ${ }^{34}$ Evaluating the reception of the negative interesse in Hungarian civil law we can ascertain that this notion can be a "false friend" for those Hungarian jurists who meet the negatives Interesse of German law and vice versa.

Unfortunately, the meaning of the attributes "positive" and "negative" is not homogeneous in legal science. A more traditional use of these attributes is connected with the classification of proprietary rights. Following an earlier tradition

\footnotetext{
33 Even Géza Marton in [47: III, 395; IV, 905, n. 41] used these concepts in a somewhat ambiguous manner (e.g. calling the positive interesse sometimes "full indemnification" while stressing the limited character of the negative interesse). The German terms of the two types of interesse have been received in Hungarian with slight Hungarization (pozitív/negativ interessze). It is to be remarked, however, that in contrast to the most European languages receiving the general notion of interest from the Latin infinitive interesse (in French interêt, in German Interesse, in Russian interes), the Hungarian language has an autochthonous substantive created in 1825 by means of substantivization of the verb érdekel documented first in the 17th c. The most remote root of these words is the very old verb ér ['to reach'] of unclear origin. The same ancient verb constitutes the origin of the words érték ['value', 16th c.] and érvény ['validity', 19th c.] [4]. The consideration of this fact can throw light on the problem, whether it was possible that B. Grosschmid could elaborate his "theory of interest" without making use of the works of Jhering [52: 205].

34 The problematical interpretation of the positive and negative interesse in Hungarian civil law being dominant also in the current literature did not help surely the development of the corresponding regulation. According to the para. 2 of the Section 6:115 of the new Civil Code of 2013 "For any loss caused to the other party by way of the conclusion of an invalid contract compensation shall be provided in accordance with the general provisions of non-contractual liability. If the party responsible for the invalidity of the contract is able to justify his conduct, he shall be liable for any loss caused to the other party by way of the conclusion of the [void] contract." This regulation contains inherent contradictions. The general rule of non-contractual liability laid down in the Section 6:519 renders possible that the tortfeasor prove that his conduct was not attributable i.e. that he acted as it could be generally expected in the given situation, cf. para. 1. of the Section 1:4. However, if the contracting party proves the lack of his culpa in contrahendo, he will be still liable for the (direct) loss emerging due to conclusion of the void contract. In the case of the failure of such an exculpation he will be liable for the full loss of the other party. While the Hungarian Civil Code of 1959 did not regulate the liability for culpa in contrahendo at all, the new Civil Code has introduced a more strict liability for this case than the general rule of delictual liability, albeit according to the wording of the rule in question the same level of liability should apply both as regards the normal causation of damage and as regards the conduct leading to conclusion of a void contract. Here I do not want to analyse the problem of the exact meaning of the "loss caused to the other party by way of the conclusion of the [void] contract".
} 
Pandectists like Julius Baron contradistinguished the positive and negative proprietary rights [3: 239]. The right of vindication as well as further rights of protection of ownership were qualified as negative rights with regard to the actio negatoria of Roman law, by which the owner denied (nego, negare) that another person had some right (e.g. a servitude) on his own thing. That is why the other proprietary rights were qualified a contrario as positive rights [15: 378]. Further legal meanings of the couple of positive-negative come closer to the normal use of these attributes. ${ }^{35}$

\section{Conclusions}

Like the entire Hungarian law, its terminology also shows mainly the impact of Austrian and German law and the German legal language still nowadays. Although Hungary belonged to the Austrian Hungarian Monarchy until 1918, it was not always the Austrian law which had the strongest impact in Hungary, namely it was often the German law, and especially the German Pandectistics which had a decisive impact on the development of Hungarian private law since the middle of the 19th century.

As far as the "false friends" in legal terminology are concerned, they emerge sometimes due to parallel developments of similar legal institutions of common (e.g. Roman law) origin, in other cases they are consequences of reception of foreign terms/concepts. E.g. if the term cause and causa respectively have different meanings in the (former) French and in the Italian law, it is a consequence of parallel developments with different results.

The false friends which have emerged in Hungarian legal terminology are much more results of reception. Until the 19th c. and since 1990 a number of legal terms received in Hungarian legal language appeared and they appear again with their original (or slightly Hungarized) name (e.g. testamentom, negatív interessze, faktoring, lízing, franchise). Normally, however, the terms received in Hungary from foreign legal cultures are translated to Hungarian.

Simple borrowings and literal translations can increase the probability of misunderstandings especially if they contain words of ambiguous interpretation (e.g., the adjective "negative" in the case of negative interesse). Creation of new terms, however, can sometimes prevent the appearing of false friends, like it was the case when a socialist principle, peculiar as it might be, was substituted for the classical principle of good faith and fair dealing in the Civil Code of 1959.

More thorough research could clarify, why "false friends" emerged in the single cases. As regards the misunderstanding of the meaning of negative interesse, both the Hungarian jurists' superficial knowledge of Jhering's theory and an intentional endeavour to limit the liability in Hungarian judicature could have a role.

Evaluating in general the characteristics of the Hungarian legal language, it can be ascertained that in spite of the foreign influences Hungarian legal language is an

\footnotetext{
35 The attribute negativ is used three times in the norm text of the Act No. V of 2013 (Section 4:116; para. 6 of Section 6:569; Section 570). The attribute pozitiv, however, cannot be found in the norm text of the code.
} 
autonomous one having a number of remarkable features which deserve attention also in comparison with the terminology of the Western legal cultures. ${ }^{36}$ I hope to have proven above that both the preparation of the Hungarian Civil Code of 1959 and that of the new Civil Code of 2013 constituted important contribution to the development of legal culture and in any case the number of "false friends" had been reduced thanks to the Hungarian codifications. The terminological distinction of the subjective and objective good faith in the new Civil Code of 2013 as well as that of invalidity and ineffectiveness elaborated already in the Civil Code of 1959 could serve as a model also in international context.

This might lead to sketch an optimistic epilogue of the present essay but still I resist the temptatio lectorem delectandi in order to call attention to some regrettable shortcomings of legal terminology. It was more than 300 years ago that Leibniz suggested to improve legal science by means of the mos geometricus. It was more than 170 years ago that Julius von Kirchmann published in 1848 his essay entitled Die Werthlosigkeit der Jurisprudenz als Wissenschaft. Such warnings had considerable impact. Many efforts have been made to improve the legal terminology in the last two centuries. Notwithstanding it has not been sufficiently elaborated so far. Besides the theoretical inconveniencies, the ambiguous, mistakable and incoherently applied terms may cause practical difficulties and sometimes these conundrums remain unresolved by the judges. Legal notions often constitute a source of misunderstanding, because ordinary lawyers are no longer aware of their history. The principle of (objective) bona fides exemplifies very well this problem. This term can be correctly interpreted par excellence only if considering its original meanings in Roman law which have determined all the later developments of this complex notion. False friends may become good friends if we know them better, including their historical background in comparative context. That is the reason why since a while I feel like understanding the very reason of an obviously exaggerated statement attributed to Joseph Story as follows: "no man could be a great lawyer unless he was an expert scholar in Greek and Latin” [55: 28]. ${ }^{37}$

Acknowledgements Open access funding provided by Eötvös Loránd University (ELTE).

\footnotetext{
36 When preparing material for his great opus Der Zweck im Recht, Rudolf von Jhering asked for data on Hungarian language (especially as regards the expressions of politeness) from a renown Hungarian philologist, Emil Ponori-Thewrewk as well as from his former student, Mihály Biermann (who became professor of Roman law in Hermannstadt [today Sibiu in Romania]). It was interesting for Jhering to learn that the Hungarian equivalent of 'virtue' (in German Tugend), namely the word erény was created (as a neologism) from the word erô ['power, strength'; in German Kraft]. Jhering stressed also that the Hungarian equivalent of 'honour' [in German Ehre], namely the word becsület was created from the word becs ['value']. Jhering observed that „Ehre ist also dem Zeugnisse dieser fünf ganz verschiedenen Sprachstämmen angehörigen Sprachen [viz. Greek, Latin, German, Hebrew, Hungarian - A. F.] zufolge der Werth der Person." [54: 226, 501].

37 Quoted by Daniel Coquillette [8: 25]. Forerunners of this idea were the Glossators criticizing the Lombard jurists and later the Humanists criticizing especially the Glossators. See e.g. Lucas de Penna (14th c.), Commentaria in tres posteriores libros Codicis Iustiniani, Lugduni 1582, 466, with reference to the lex lombarda to be qualified as fex; see furthermore Koschaker [30: 109], with reference to François Rabelais.
} 
Open Access This article is licensed under a Creative Commons Attribution 4.0 International License, which permits use, sharing, adaptation, distribution and reproduction in any medium or format, as long as you give appropriate credit to the original author(s) and the source, provide a link to the Creative Commons licence, and indicate if changes were made. The images or other third party material in this article are included in the article's Creative Commons licence, unless indicated otherwise in a credit line to the material. If material is not included in the article's Creative Commons licence and your intended use is not permitted by statutory regulation or exceeds the permitted use, you will need to obtain permission directly from the copyright holder. To view a copy of this licence, visit http://creativecommons.org/licen ses/by/4.0/.

\section{References}

1. Amagyarnyelvnagyszótára [=Comprehensive Dictionary of Hungarian Language]. 2018. vol. VII, Budapest: http://nagyszotar.nytud.hu.

2. Bárczi, Géza. 1941. Magyar szófejtô szótár [= An etymological dictionary of Hungarian]. Budapest: Kir. M. Egyetemi Nyomda.

3. Baron, Julius. 1896. Pandekten [9. Aufl.]. Leipzig: Duncker \& Humblot.

4. Benkő,Loránd (ed.). 1967-1976. A magyarnyelv történeti-etimológiai szótára [= Historical-etymological dictionary of the Hungarian language], I-III, Budapest: Akadémiai Kiadó.

5. Bozóky, Alajos. 1874. A római jog Pandektáinak tankönyve [=A textbook of the Pandects of Roman law]. Budapest: Franklin.

6. Brósz, Róbert. 1985. Die Rolle der Gewohnheit (des Gewohnheitsrechts) im Laufe der Entfaltung und Entwickelung der ,longi temporis praescriptio(nes)“. Acta Jur. et Pol. Szeged., 33.

7. Brownsword, Roger. 1994. Two concepts of good faith. Journal of Contract Law 7: 196.

8. Coquillette, Daniel. 2005. "Mourning Venice and Genoa": Joseph Story, legal education and the 'lex mercatoria. In From 'lex mercatoria' to commercial law, ed. Vito Piergiovanni. Berlin: Duncker \& Humblot.

9. Duden, 2001. Herkunftswörterbuch, Etymologie der deutschen Sprache [3. Aufl.]. Mannheim: Dudenverlag.

10. Figge, Wilhelm. 1902. Die relative Unwirksamkeit der Rechtsgeschäfte. Rostock: Diss. Univ.

11. Földi, András. 2001. Zur Frage der Gültigkeit und der Wirksamkeit im modernen Zivilrecht. In Festschrift Ferenc Benedek, hrsg, ed. Gábor Hamza et al. Pécs: Dialóg Campus.

12. Földi, András. 2003. Rinascita del principio della buona fede oggettiva in Ungheria. In Il ruolo della buona fede oggettiva nell'esperienza giuridica storica e contemporanea, cur, vol. III, ed. Luigi Garofalo. Padova: Cedam.

13. Földi, András. 2005. Zur Begriffsgeschichte der Verantwortung. In Studia Zoltán Péteri dedicata, ed. István H. Szilágyi and Máté Paksy. Budapest: Szent István Társulat.

14. Földi, András. 2007. Remarks on the notion of 'bona fides'. Annales Univ. Sc. Budapest. sectio iur 48: 53.

15. Földi, András. 2009. Historic and dogmatic aspects of the triad of proprietary rights. In Scritti in onore di Generoso Melillo, vol. I, ed. Antonio Palma. Napoli: Satura.

16. Földi, András. 2013. Monism and dualism in the history of arra. In Liber amicorum Guido Tsuno, ed. Fritz Sturm et al. Frankfurt am Main: Vico.

17. Földi, András. 2014. Traces of the dualist interpretation of good faith in 'ius commune' until the end of the $16^{\text {th }}$ century. Fundamina 20 (1): 312-321.

18. Frank, Ignác. 1845. A közigazság törvénye Magyarhonban [=Private law in Hungary], vol. I. Buda: M. Kir. Egyetem.

19. Giannantonio, Benacchio. 2016. Diritto privato della Unione europea, 7a ed. Padova: Cedam.

20. Glare, Peter (ed.). 2012. The Oxford Latin Dictionary, 2nd ed. Oxford: Oxford University Press.

21. Grimm, Jacob et al. 2020. Deutsches Wörterbuch von Jacob Grimm und Wilhelm Grimm auf CD-Rom und Internet [http://dwb.uni-trier.de/de/], Trier: Kompetenzzentrum.

22. Hamza, Gábor. 2009. Entstehung und Entwicklung der modernen Privatrechtsordnungen und die römischrechtliche Tradition. Budapest: ELTE Eötvös Kiadó.

23. Henfner, János. 1855-1856. Római magánjog [=Roman private law], I-III. Pest: Heckenast.

24. Jhering, Rudolf. 1861. „Culpa in contrahendo“ oder Schadensersatz bei nichtigen oder nicht zur Perfection gelangten Verträgen. Jherings Jahrbücher 4: 1.

25. Jowitt, William. 1959. The Dictionary of English Law, vol. II. London: Sweet \& Maxwell. 
26. Juenger, Friedrich. 1995. Listening to law professors talk about good faith: Some afterthoughts. Tulane Law Review 69: 1253.

27. Kaser, Max. 1971. Das römische Privatrecht [2. Aufl.], vol. I. München: Beck.

28. Kocsis, Zsuzsanna. 2016. Az uzsora szó nyelvtörténete [=Linguistic history of the word "uzsora"]. In Tanulmányok az uzsoráról [= Studies on usury], ed. Mihály Filó. Budapest: ELTE Eötvös Kiadó.

29. Koessler, Maxime, and Jules Derocquigny. 1928. Les faux amis ou les pièges du vocabulaire anglais: conseils aux traducteurs. Paris: Vuibert.

30. Koschaker, Paul. 1966. Europa und das römische Recht [4. Aufl.]. München: Beck.

31. Kovács, Ferenc. 1964. A magyar jogi terminológia kialakulása [= Coming into being of the Hungarian legal terminology]. Budapest: Akadémiai Kiadó.

32. Le Trésor de la Langue Française informatisé. 1994. [http://stella.atilf.fr.], Nancy: Université de Lorraine.

33. Menyhárth, Gáspár. 1914. Érvénytelenség és hatálytalanság, figyelemmel a magyar ptv.-könyv javaslatára [=Invalidity and ineffectiveness, with regard to the Draft of the Hungarian Civil Code]. In Emlékkönyv Farkas Lajos tanárságának 45. éve alkalmából, Kolozsvár: Stein János Egyetemi Könyvkereskedése.

34. Nánásy, Benjámin. 1798. Testamentom a' magyar országi törvények szerént [The last will in Hungarian law]. Pesth: Trattner.

35. Petrucci, Aldo. 2019. Manuale di diritto privato romano. Torino: Giappichelli.

36. Rainer, Johann. 2003. La buona fede ('Redlichkeit') nel diritto austriaco. In Il ruolo della buona fede oggettiva nell'esperienza giuridica storica e contemporanea, vol. III, ed. Luigi Garofalo. Padova: Cedam.

37. Scalisi, Vincenzo. 1971. Inefficacia (diritto privato). In Enciclopedia del diritto, XXI, Milano: Giuffrè.

38. Schedel [Toldy], Ferenc. 1843. Törvénytudományi múszótár [=A dictionary of terminology of legal science]. Buda: M. Kir. Egyetem.

39. Schedel [Toldy], Ferenc, and Mihály Vörösmarty. 1835. Magyar és német zsebszótár [=A pocket dictionary of Hungarian and German], Pest: M. Pest: M. Kir. Egyetem.

40. Schilling, Bruno. 1844. Pandektenrecht für Studirende. Berlin: Heymann.

41. Seckel, Emil. 1907. Heumanns Handlexikon zu den Quellen des römischen Rechts [9. Aufl.]. Jena: Gustav Fischer.

42. Siklósi, Iván. 2014. Nemlétező, érvénytelen és hatálytalan jogügyletek a római jogban és a modern jogrendszerekben [= Theoretical and dogmatic questions of the inexistence, invalidity, and ineffectiveness of juridical acts in Roman law and in modern legal systems]. Budapest: ELTE Eötvös Kiadó.

43. Siklósi, Iván. 2017. Some thoughts on the inexistence, invalidity and ineffectiveness of juridical acts in Roman law and in its subsequent fate. Journal on European History of Law 8 (1): 90-97.

44. Spoto, Giuseppe. 2001. Le invalidità contrattuali. Napoli: Jovene.

45. Suhayda, János. 1862. A magyar polgári anyagi magánjog rendszere [= The system of Hungarian substantive private civil law]. Pest: M. Kir. Egyetemi Könyvnyomda.

46. Szabó, Béla. 2001. Ignác Frank. In Juristen. Ein biographisches Lexikon, hrsg, ed. Stolleis Michael. München: Beck.

47. Szladits, Károly (ed.). 1941. Magyar magánjog [= Hungarian private law], vol. III-IV. Budapest: Grill.

48. Tallon, Denis. 1994. Le concept de bonne foi en droit français du contrat. Roma: Centro di studi e ricerche di diritto comparato e straniero.

49. Tárkány Szücs, Ernô. 1981. Magyar jogi népszokások [=Hungarian legal folkways]. Budapest: Gondolat.

50. Till, Ernst. 1914. Fehlerhafte Rechtsgeschäfte. Grünhuts Zeitschrift, 40: 209.

51. Trabucchi, Antonio. 2001. Istituzioni di diritto civile, 40a ed. Padova: Cedam.

52. Vékás, Lajos. 2017. Magánjogi kérdések jogelméleti megközelítésben Peschka Vilmos múveiben [= Problems of private law examined by methods of legal philosophy in the works of Vilmos Peschka]. Jogtudományi Közlöny, 72: 197.

53. von Haimberger, Anton. 1835. Reines Römisches Privat-Recht. Wien: Schulbücher Verschleiß-Administration.

54. von Jhering, Rudolf. 1898. Der Zweck im Recht [3. Aufl.]. Leipzig: Breitkopf \& Härtel.

55. Warren, Charles. 1908. History of the Harvard Law School, vol. II. New York: Louis Publishing Company.

56. Windscheid, Bernhard, and Theodor Kipp. 1906. Lehrbuch des Pandektenrechts [9. Aufl.]. Leipzig: Rütten \& Loening. 
57. Zlinszky, Imre. 1880. A magyar magánjog mai érvényében [= Hungarian private law as it is effective nowadays]. Budapest: Franklin.

58. Zlinszky, János. 1985. Die historische Rechtsschule und die Gestaltung des ungarischen Privatrechts im 19. Jahrhundert, Acta Jur. et Pol. Szeged., 33.

Publisher's Note Springer Nature remains neutral with regard to jurisdictional claims in published maps and institutional affiliations.

\section{Affiliations}

\section{András Földi ${ }^{1}$}

$\triangle$ András Földi

andras.foldi@ ajk.elte.hu

1 Eötvös Loránd Tudományegyetem, Budapest, Hungary 